\title{
Bureaucracy and Creative Complexity - Empirical Analysis of Problem Solving Effectiveness Within Organizations
}

\author{
Eva Bolfíková* \\ e-mail:eva.bolfikova@unipo.sk
}

Ivana Pirohová*

e-mail:ivana.pirohova@unipo.sk

\section{Martina Lenhardtová* e-mail: martina.lenhardtova@unipo.sk}

Katarína Mayer*

e-mail: katarina.mayer@unipo.sk

\section{Marek L u káč *}

e-mail:marek.lukac@unipo.sk

\section{Daniela Hrehová}

Technical University, Department of Social Sciences, Košice, Slovak Republic e-mail:daniela.hrehova@tuke.sk

* University of Prešov, Faculty of Humanities and Natural Sciences, Department of Andragogy, Slovak Republic

ABSTRACT The study presents a theoretical and empirical analysis of bureaucratic and non-bureaucratic tools of problem solving within organizations that are perceived as complex adaptive systems. Drawing upon Stacey's theory of creative complexity, we created a research framework by developing five indicators (dimensions): disintegration, irregularity, instability, disruption, and deviation (each of these indicators was further operationalized into six items of the questionnaire). With the research hypothesis in mind, we analysed the inclination towards the decision-making following the logic of bureaucracy (linear environment) on one hand, and the logic of creative 
complexity on the other. The level of inclination was analysed in comparison to the problem solving effectiveness performing repeated measures MANOVA - (intersubject factor - EFFECT: 1. successful 2. unsuccessful). The participants in this study were 743 employees from various organizations. The questionnaire method K-T-1 was employed in this research. The results of the analysis indicate that the problem solving success rate is significantly differentiated in three dimensions: irregularity, instability and deviation. A higher inclination towards creative complexity was determined in two dimensions: deviation and regularity. A higher success rate of problem solving following the logic of bureaucracy was determined in the dimension of instability.

Key words: bureaucracy, complex adaptive system, organization, creative complexity.

\section{Introduction}

Decision-making in any situation can be understood as a process that leads to $a$ problem solution, goal accomplishment or creation and selection of varied activities. It is a process that reflects the key philosophy, which determines the way how the topic of decision-making and the tools that enter into the decision-making process are perceived. The philosophy of complexity provides us with very effective means and thus represents a paradigm base whose application can be significantly more effective in comparison to applying procedures based on the traditional approach - bureaucracy.

Complex analysis, or an analysis in the environment of complex adaptive systems, is not a product of modern science. A lot of evidence about this way of thinking can be found in the medieval cultures of China, and in the ancient Greece and Egypt (Daneke, 2005). However, a strict religious doctrine and conservative government slowed down the development of complexity in the knowledge of nature and society in the Western world quite significantly (Baoquan and Guishi, 2002). In spite of that, the theoretical composition of system analysis was still reflected, especially in astronomy and mathematics. This approach sought to understand the nature and character of interrelations between different phenomena.

Today, complexity analyses are present in all areas of scientific knowledge. In the organizational environment, these analyses have a very specific character given the variety of issues, areas, and relational and causal framework. The research into the nature of the decision-making process in problem solving, can be seen as an effort to study the potential of development and change within organizations (Daneke, 2005). Moreover, it can provide answers to all questions that the academics and practitioners interested in the issues of bureaucracy have raised over the past decades.

What is complexity science? A large number of scientific publications have already addressed this issue (Wallis, 2009; Allen, 2001; Morcöl, 2001), creating a vital learning area full of efforts to escape the illusions of truth, as a by-product of the knowledge 
based on the classical Newtonian scientific paradigm. " "The science of complexity studies the fundamental properties of nonlinear-feedback networks and particularly of complex adaptive networks" (Stacey, 1996:10). Wallis (2009) summarizes the mutually exclusive dimensions of the complexity theory as: predictability, emergence, fitness, systems, action, information, goals, strategies and time (Wallis, 2009:32).

A complex adaptive system comprises numerous agents interacting according to particular rules; the system is adaptive in the way that the agents through their interactions co-adapt, co-learn, and co-evolve (Maguire and McKelvey, 1999). Given that agents co-evolve, the processes and structures that emerge from their interactions are dynamic, i.e. self-organization "is emergent as a result of the interdependent behaviour of agents who act on local information" (Surie and Hazy, 2006:14).

At a threshold of energy and complexity, systems develop new parameters of behaviour - the "emergent ${ }^{2}$ phenomena" (Chamberlin, 2009; Hazy and Ashley, 2011; Hodgson, 2000). Organizations often experience change as an emergent process (Lissack and Letiche, 2002).

The study aims to present one of the methods for performing an empirical analysis in the research into the differences between the classical bureaucratic and complex approach to problem solving and decision-making in terms of solution effectiveness. The theoretical framework presents the key theories and concepts pertaining to the purpose of our research. They discuss the logic of deliberation in the environment, which is defined by the attributes of a bureaucracy model (M. Weber) on one hand, and creative complexity (R. D. Stacey) on the other. In the empirical analysis, we examined the differences in the effectiveness of problem solving within organizations. We also studied the character of decision-making processes determining the level of inclination towards bureaucratic or complex tools. The method of questionnaire was used to gather the data.

$\mathbf{1}$ Complexity science as a term encompasses a variety of techniques, disciplines, paradigms, and perspectives, including nonlinear dynamic systems theory, nonequilibrium thermodynamics, dissipative structures, catastrophe theory, the theory of self-organized criticality, chaos and fractal theory, self-organization, artificial neural network learning/training theories, „swarm“ learning theory, statistical physics, thermodynamics, entropy, power-law scaling phenomena, differential geometry, information theory, critical phenomena and phase transition theory, turbulence theory, spatiotemporal correlation functions, stochastic and deterministic differential equations, and social, economic network theory (Lissack and Letiche, 2002).

2 Emergence can be defined as an overall system behaviour that comes out of the interaction of many participants behaviour that cannot be predicted or even envisioned from knowledge of what each component of a system does in isolation. (Casti, 1997). 


\section{Classical model of bureaucracy in a setting of uncertainty}

The way in which social systems can be organized is defined by a degree of unique actualization of the attributes pertaining to two model types, which are, in their purest form, perceived as ideal types - bureaucracy and non-bureaucracy, or postbureaucracy (Heckscher and Donnellon, 1994). The history of organization theories enables us to follow the development and specifics of looking at the essence of organizations where it is possible to identify the level of inclination towards one of these models. The differences are usually defined taking into consideration the key attributes - as the opposites: 1. rules (freedom vs. control), 2. arrangement of relationships (horizontal vs. vertical), 3. processes (stability vs. development and change), 4. behaviour (algorithms vs. adaptation, flexibility, creation), 5. values (objectives vs. missions).

The classical model of bureaucratic organization (Weber, 1947; Taylor, 1947) has been surrounded by many doubts - in all its attributes. Theoretical and empirical analyses indicate that the "certainties" of a rational model, which are presented as a guarantee for efficiency of the systems arranged in such a way (formal organizations and society as a whole), are indeed their greatest "uncertainties". In his analysis of bureaucratic disfunctions, Merton (1957) points to the real mechanisms of formal rules (ritualism of bureaucracy). Additionally, in his analysis of unintentional consequences (Merton, 1936) of purposeful behaviour, he challenges rationality, the very core of the classical model of bureaucracy (Merton, 1952). A trend of human relations in organizational analysis challenges the effectiveness of strong formalization and impersonality (Barnard, 1938; Homans, 1950; Golembiewski, 1979). Crozier (1970) shows the reality of bureaucracy as a strongly bierarchical and centralized system. He also addresses the communication and relationships within bureaucratic organizations (Crozier, 1964). Other authors were also concerned with the ineffectiveness of the hierarchical system and called for the creation of alternative ways of arrangement (White, 1969). It is beyond the scope of this study to present a comprehensive review of bureaucracy criticism. The aim of this study is to introduce the tools of the complexity theory into the interspace between the bureaucratic and non-bureaucratic ideal type of organization. The question that arises here is:

\section{Is bureaucracy really as ineffective as documented in many analyses?}

M. Weber's ideal type of bureaucracy [1922] presents a way of possible organization of power relations (legitimacy) as an asymmetric power relation between the power holders (minority) and the power subjects (majority). The abstractly defined ideal types of bureaucracy and post-bureaucracy can be seen as being at the far ends of the continuum, when the degree of empirical actualization of the attributes of one or the other model determines an organization's position between power and nonpower (cooperative) arrangement. This implies that every organization exhibits, to a certain extent, the attributes of both ideal types. The efficiency of an organization is determined by the degree of goal accomplishment (in post-bureaucracy - mission completion), while these goals are set by the subject who has some conscious ideas about them (with regard to the character of manifest and latent goals). If we 
conclude that the functioning of bureaucracy is ineffective, one question arises: For whom is it ineffective? The primary objective of the bureaucratic arrangement of relations is the establishment, exercise, and maintenance of power. This objective corresponds with the way how the rules, structure, relationships, division of labour, etc. are formed. The attributes of bureaucracy can be considered as general attributes for defining formal organizations. Every organization must have rules, organizational arrangement, and structures (of objectives, positions, activities, and resources). They do not necessarily lead to ineffectiveness, though. The problem of ineffectiveness in bureaucracy can be understood as a reflection from the perspective of those who do not set the objectives. The empirical character of all tools (attributes) of organizational functioning reflects the character of the target structures.

Organizations as social systems are characterized by their duration and do not rely on presence. Formally distinguishing themselves against their environment by making decisions on decisional premises and membership criteria, organizations are able to co-ordinate huge numbers of interactions. "They achieve the miracle of synchronizing interactions, in spite of the fact that these always and necessarily take place simultaneously, in their pasts and in their futures" (Luhman, 1997:836-837).

Organizations viewed as social systems - in an interaction with the idea of bureaucracy - blend their value potential with the management of society as a whole. The key values in the approach to the society (state) management are reflected in the current environments of different types of organizations, and are defined with regard to the specifics of their objectives. Bureaucracy is seen as one of the possible types of social system organizations, where the rule and structure are the dominant factors of the establishment, exercise, and maintenance of power. This type is in counter-position with the types of organizations that are based on value schemes and principles (in connection with missions and visions). Both of these types could be viewed in the instrumentation of the classical (Newtonian) paradigm, or the complexity paradigm. The clarification and study of these organizations (and ultimately the consequences for practice, too) are then shifted into a specific area of complex adaptive systems providing an adequate picture of the nature and character of the functioning of organizational environment (Daneke, 2005; Crawford at al., 2009; Moldoveanu, 2008; Goldstein and Hazy, 2008; Varga et al., 2009).

\section{Regulation and rationality in complexity}

Every organization can be seen as a complex adaptive system - multi-agent, multifunctional, multi-level, and multi-instrumental, etc. The question is whether the way in which organizational environment is managed, corresponds with this definition and if so, to what extent. Organizations are complex adaptive systems (Thietart and Forgues, 1995) comprised of the people "who experiment, explore, self-organize, learn and adapt" to their changing environments (Carlisle and McMillan, 2006:3-4). Complexity manifests itself in different forms and can be subdivided into four types: 1. dynamical - describes the behaviour of the system, 2 . organizational - describes the network of interactions, 3. cognitive - describes the challenge that an individual 
faces, 4. inter-relational - describes the behavioural and psychological skills of individuals (Boschetti et al., 2001).

In the study and management of organizational systems, the concept of rationality is linked with the concept of homo economicus. In line with Weber's ideal type of bureaucracy, the concept of rationality represents a key attribute of classical organization. Having in mind the maximization of a subject's benefit and organization's efficiency in terms of its goals, the calculation in the decision-making process focuses on strong formalization, standardization, impersonality, specialization, external control algorithmization, but specifically on predictability in the system. All this in order to sustain the regulation and control in the system. The above-mentioned comments of the authors who challenge the effectiveness of bureaucracy and its instruments suggest that this is exactly what bureaucracy "fails to achieve". It results in the emergence of unforeseen events - reactions and implications (Boschetti, 2011).

Can artificial regulation be effective in the systems that possess the natural attributes of complex adaptive systems? If so, to what extent?

In spite of the apparent efforts to respond effectively to the complexity of the internal and external environment, bureaucracy is constantly producing behaviour that is based on a linear arrangement creating a dramatically dissonant environment (Desai, 2010). Bureaucracy needs to react to the variability of the environment, which is essentially unpredictable in the long term (Kemp, 2009), and does so by developing strategies of simple procedures for moving from point A to point B by applying the predetermined abstract algorithm. Uniformity acts here as one of the basic principles for the structure development (objectives, values, positions, rules, activities), while most of the system's energy is oriented towards its maintenance. It is a natural effort of the system to maintain its key attributes in the given environment, and is manifested in linear and nonlinear systems. The differences between these systems can be identified with respect to the instruments used, for example, different control mechanisms (Goertzel, 1994). Real complexity is not linear and cannot be studied adequately as a model of "A causes B" in a situation wherein "B causes A" (Eide, 2009).

\section{Stacey's legitimate and shadow network}

The human environment (social systems) is characterized by multi-interactive behaviour. Stacey (1996) distinguishes these interactions in the legitimate network and the shadow network; both types of networks are non-linear, which also requires a different approach in decision-making (Priesmeyer, 1992).

Legitimate network interactions consist of links that are either: 1. formally and intentionally established by the most powerful members, or 2 . established by well-understood, implicit principles widely accepted by members, and forming a shared culture or accepted ideology (Stacey, 1996). The organizational environment is arranged in a way so that it maintains the "certainty and safety" in relation to unforeseen situa- 
tions under the illusion of effective behaviour in relation to the organizational objectives. Interactions are characterized by uniformity, conformity, and repetition, and are limited by the system of impersonal rules. A part of the organizational culture is also a strict control and the system of sanctions. Typical of linear systems is: 1. there is a single option of reaction (algorithms) to certain stimuli, 2. All outputs are proportional to inputs, 3. the system is "only" a sum of its parts (Stacey, 1996).

Linear systems are also characterized by non-linearity in their outputs, as the use of any algorithm naturally produces a range of unpredictable reactions. The dominant schemes face in their application a number of situations that are not contained within the limits defined by the algorithms (the result of significant generalization).

Shadow networks are spontaneously and informally established by individual agents among themselves during the course of interacting in the legitimate system (Stacey, 1996). These networks operate in parallel with the legitimate networks, and create their own culture which is unique in its rules, interactions, activities, and responses to impulses from both internal and external environments. Legitimate and shadow networks operate in parallel, but not independently; their interaction creates a specific organizational environment and has important (either positive or negative) implications in relation to the functioning of the organization in its environment (Dooley and Letiche, 2009). Accordingly, shadow networks may be either supportive or can sabotage the legitimate system (Blauner, 1964).

A shadow network is quite clearly nonlinear. It means that the production of responses to stimuli is unlimited, variable, open to correction of errors, and flexible concerning the feedback, since it has no clear boundaries or limits.

\section{Organizational creativity}

Organizational creativity flows from the tension between legitimate and shadow systems (Stacey, 1996). The common characteristics of complexity and creativity can be defined as follows: 1. a phase of transition, 2. a state of paradox, 3. the actualization of archetypes, 4. creative destruction, 5. a critical point for control parameters (Winnicott, 1965).

In practice, the creativity of an organization can be defined in terms of learning in mutual interactive sharing of functional behaviour schemes. A phase of transition is characterized by the distinction between the dominant and recessive part of schemes, always with respect to the task and activity type. The dominant schemes are created by the legitimate system in the organization; these may be in tension not only with the schemes of the shadow system, but also with the current configuration of input information (agents, processes, stimuli ...). The paradox status is then a situation where a legitimate system strives to sustain the status quo while its shadow system seeks to alter it. Archetypal patterns are always linked to the set algorithms of behaviour (generally accepted rules, procedures, and principles). Their actualization leads to the production of deviations from the standard in individual and group application of archetypes in the emergent environment. 
Creative destruction is very important in creating a space for innovation in an environment that tends to maintain the status quo even in the continuously evolving conditions. The behaviour of complex systems is characterized by the constant development of new behavioural patterns in a multi-interactive design; destruction is here a natural condition for establishing new schemes. The critical point for control parameters refers to a situation when the boundary is created, and beyond that boundary there is a necessary shift from the zone of (illusory) stability to the learning processes at individual, group and organizational level. (Stacey, 2001). This situation emerges in the interaction between the dominant and recessive schemes, and legitimate and shadow systems in a complex adaptive system. Stacey (1996) identifies five control parameters: the rate of information flow, the degree of diversity, the richness of connectivity, the level of contained anxiety, and the degree of power differentials.

\section{Research framework}

In an attempt to artificially regulate (control) "its" environment, bureaucracy reduces the complexity of situation by referring to the relevant rule, prepared in advance for the given case (or file cases) as the most effective solution. Even in this case the participant can choose how he or she justifies the application of the rule (whether he or she notifies the client that the creation of rules is not in his or her competence, or he or she convinces the client that the solution offered is the most effective one, etc.). Complex learning (Argyris and Schön, 1978), on the other hand, is characterized by the availability of alternative strategies and choices.

An important concept here is the expected or unexpected behaviour (surprise) of the participants and a degree of regulation or freedom to develop strategies when solving problems and situations (Smith, 1996). Important also is the nature of collaborative knowledge creation processes (Jakubik, 2008).

The process of self-organization is typical of those complex adaptive systems that are far from equilibrium, and results in the creation of order in a system by internal interactions between agents leading to stronger adaptive capability (Saadia, 2009). There is a sufficient quantity of literature available on the issue of self-organization for the domain of management from theoretical perspective (Goldstien, 1994; Axelrod and Cohen, 2000, and others); significantly fewer studies have been devoted to empirical research (Bokeno, 2009).

Introduction of the complexity theory into the management of organizations leads away from the basic propositions of knowledge application in natural sciences to the sphere of social sciences. The majority of self-organization in management literature (Ashby, 1947, Molleman, 1998) has a common topic of: "1. creation of organization without external direction or external order, 2. joint action by the constituents of the system for the achievement of a shared goal - higher organization, complex patterns, products, or transactions" (Saadia, 2009:4). 
In order to examine the space between the patterns defined by the idea of classical bureaucracy and the possibilities of creative complexity, we identified five indicators.

Disintegration. A key feature of organizations as complex adaptive systems is the ability to learn in comprehensive manners. All these systems become creative in the moment when they conveniently operate on the edge of disintegration, in a kind of a phase transition between a stable zone of operation and an unstable or disorder regime (Stacey, 1996:13). Creativity then lies in abandoning the concepts of stability of reactive behaviour based on adhering to the algorithms in the abstraction of anticipated effective solutions. Disintegration is reflected in a tension between what is prepared, learnt, expected, predictable and controllable in terms of linearity and what is manifested as the vitalization of the complex environment non-linearity. It is usually initiated by the shadow system in the organization. Creativity is both a prerequisite and a result of self-regulation (Clapham, 1997).

Irregularity. The theory of dissipative structures explains the behaviour of the system in terms of the continuous creation of new patterns differing in space and time. It is therefore impossible to assume that the artificially created behaviour algorithms will be applicable under any circumstances - and even effective in relation to the functionality of the system (problem solving, task solving), and that a regular constant application of these algorithms will ensure the system's stability. This is especially present in those types of systems which are characterized by an asymmetric arrangement of relations between agents (system of power), where the input conditions are already far from equilibrium. Despite the defined patterns, the management of decision-making in problem solving still works as the development of structures in unstructured decision-making processes (Mintzberg, Raisinghani and Théorêt, 1976). A complex system sensitive to the input conditions is always operationally ready and capable of producing a large amount of changes towards the qualitatively different behavioural patterns, resulting in irregularity, unpredictability, and instability of behaviour in the system, including disproportions between the stimulus and effect. The interplay between rules and randomness is the essence of creativity (Goertzel, 1994:119). This means that the existence and functionality of rules, on one hand, and randomness on the other, create boundaries that define an autonomous system in the environment, while randomness is a term used to describe a situation when we cannot identify what gives rise to the phenomena and processes in deterministic systems.

Instability. An organization of any kind, whether in nature or in human action, can be thought of as an interplay of stability and change (Stacey, Griffin and Shaw, 2000). The effort of the organization is to maintain the stability of functionality in the constantly updated conditions, while respecting the space for innovation and change. In this way, organizational strategies constantly oscillate between continuity on one hand, and creativity and changes on the other. A condition for operational balance is defining the resources, which ensure the effectiveness of regulation, control and stability, or resources, which bring about instability and change. 
The relations between the elements of the systems and their structuring are characterized by a certain tension that McKelvey (2002) regards as an essential necessity. The elements of the system are dependent on information, or environment mapping, and always oscillate between stability and instability (change) as a morphogenic process creating a structural elaboration that is discussed here as emergence and self-transcending constructions (Goldstein, 2007).

The behaviour of the system, as well as the agents, is unpredictable in complex systems. The high degree of sensitivity to input conditions is reflected in the paradox of simultaneous presence of stability in an archetypal or dispositional form and instability in specific actualization (Stacey, 1996). The theory of dissipative structures explains how the system uses the disorder to generate a new order through the process of spontaneous self-organization. The state of equilibrium implies that the behaviour of the system is symmetrical, uniform and regular (system attributes do not change in time). For complex systems, this is just a model situation, since vital systems evolve far from equilibrium. Then a movement from a perfectly orderly, symmetrical situation to one of some more complex orders occurs through a destabilizing process (Stacey, 1996).

Self-organization is a process, which in case of the occurrence of critical parameter values of the system control ensures the production of new patterns without any blueprint. These new patterns cannot be explained with respect to the behaviour of the agents only; emergency moves towards synergy results of all actualized components and processes. In the emergent models, stability is produced by the tension between negative and positive feedback. Stacey (1996) also lists the sources of instability: "1. the process of amplifying small changes, 2. the operation of competition and the use of unpredictability as a survival strategy by other interconnecting systems, and 3. the exposure to creative tensions set up by the recessive schema, that is, cross-fertilization and flux" (Stacey, 1996:205).

Dismuption. Any disruption to the schemes, which were developed under the illusion of system stabilization in its functionality in a complex environment, is perceived as an undesirable interference, unless the positive results of these processes occur. While bureaucracy requires a behaviour within the limits of the given algorithms (under the threat of sanctions), every disruption of the expected behaviour is described as negative. In organizations viewed as complex adaptive systems, we can talk about creative destruction, which brings about the production of new behavioural patterns and the natural response to the change of input conditions in any aspect. The dominant schemes are part of the history and memory of the prior learning. As far as the task fulfilment is to become a functional process in a complex environment, deviations and changes have to occur for the sake of innovation in continuous manifestations of creative destruction. The key changes then affect mainly the hierarchical power structures, division of labour and flexibility of the system. "New combinations, which may appear discontinuously" (Schumpeter, 1934: 66) produce a continual change. 
Disruption and discontinuous change are commonly explained in relation to the catastrophe theory and the behaviour of the systems in a turbulent environment. Perhaps, discontinuous development in a system can be considered not only a result of the emergence of critical moments (Stanley, 2009) in internal and external interactions, but also a natural manifestation of continuous changes, some of which can also be expected. The system then oscillates within the limits of expected and unexpected behaviours and their results.

Deviation. In the self-organizing systems, there is no central controller to tell actors what to do, nor does any actor have complete knowledge of the circumstances surrounding their actions. One result of such self-organizing activities is coming into being of the novel, unpredictable patterns (Tapsell and Woods, 2008). This means a constant production of new variants of behaviours (problem solving), which in relation to standard algorithms function as deviations (from standards, rules, established patterns controlled by sanctions). Non-pathological deviation development takes place together with the need for requisite variety, which contributes to a change in selection processes that resemble our discussions of far from equilibrium states and non-linearity.

The inclination of workers in a problem/situation solving towards the logic of linear or non-linear conditions in an organization was examined in comparison to the effectiveness/success of the result/solution. The research question focused on establishing the success rate of the employed instruments. The aim of the research was to determine the nature of behaviour and decision-making in specific situations with respect to the rate of actualization of classical or complex attributes of the strategy development.

Hypothesis: Effectiveness/success rate of problem solving within organizations is differentiated with regard to the inclination of the employees towards the logic of either bureaucratic or creative complexity methods of decision-making in the given dimensions (indicators).

\section{Method}

The empirical data, needed for the analysis and the research hypothesis testing, were collected through a questionnaire. Research questionnaire K-T-1 has been structured in line with the research objective. We examined the level of inclination towards creative complexity or bureaucracy environment during the decision-making process in five dimensions (creative complexity indicators).

- "Disintegration" - of the established system, processes, structures, methods, consensus and standards.

- "Irregularity" - of the problem, instruments, ideas, themes, relations and management.

- "Instability" - manifested in the trust, security, support, control, relations and change. 
- "Disruption" - of the learnt, well-handled behaviour, original resources, the concepts of solution and continuity.

- "Deviation" - from traditions, expectations, objectives, standards, stable and positive, and from the known or predictable.

The operationalization of the given indicators to measurable items was prepared while taking into account the movement within the environment (complex) which is extremely challenging in terms of the organization and creation of clearly defined structures in a standard manner. The result of the operationalization is a set of items among which many overlap and can therefore be relevant for more than one indicator.

The factor structure of the set of items shows that when a successful problem solution is considered, the decision-making mechanisms are structured into two factors: $\mathrm{F} 1=$ disintegration and deviation, F2 $=$ disruption and instability. Unsuccessful problem solution is characterized by more significant internal structuring of the items, even with regard to decision-making indicators in the complexity environment: $F 1=$ disintegration, $F 2=$ instability, F3 = disruption and deviation, $F 4=i r-$ regularity.

The questionnaire was divided into two blocks. The first part of the questionnaire follows the use of the decision-making attributes in a successful solution to a problem situation [Nebeker, 1975], while the second part focuses on the decision-making in a situation of an unsuccessfully solved problem. Interviewees responded to 30 items regarding successful problem solving and to 30 identical items regarding unsuccessful problem solving.

In both blocks, the respondents were asked to describe the most memorable or the last problem situation they were trying to solve as part of their working tasks in their place of work. In the first block, they were to describe the situation with a positive result (successful solution) and in the second, they were to describe the situation with a negative result (unsuccessful solution). The respondents then commented on their choice of method and decision-making.

To measure the level of inclination towards the bureaucratic or the complex attributes of decision-making we used a seven-point scale. The responses were polarized towards the bureaucratic approach ( $1^{\text {st }}$ point on the scale) on one hand, and towards the creative complexity approach ( $7^{\text {th }}$ point on the scale) on the other hand. Thus, on one hand, there is a strict abidance by the rules in terms the bureaucratic way of thinking and on the other hand, the possibility of using creative approaches of learning organizations in complexity. The lower the mean score, the higher the inclination towards bureaucratic attributes. The higher the mean score, the higher the inclination towards creative complexity attributes.

The dependent variables are all decision-making attributes, items, defined within the operational process of complexity indicators in case of successful and unsuccessful problem solving. The independent variable is the intersubject factor "EFFECT" with variants: 1 . successfully solved, 2 . unsuccessfully solved. 
Table 1

Reliability tests' results (Cronbach's $\alpha$ )

\begin{tabular}{|l|c|c|}
\hline Problem situation solution & Indicators & $\boldsymbol{\alpha}$ \\
\hline \multirow{3}{*}{ Successful solution } & Disintegration & 0.86 \\
\cline { 2 - 3 } & Irregularity & 0.81 \\
\cline { 2 - 3 } & Instability & 0.80 \\
\cline { 2 - 3 } & Disruption & 0.85 \\
\cline { 2 - 3 } & Deviation & 0.88 \\
\hline \multirow{3}{*}{ Unsuccessful solution } & Disintegration & 0.89 \\
\hline & Irregularity & 0.83 \\
\cline { 2 - 3 } & Instability & 0.85 \\
\cline { 2 - 3 } & Disruption & 0.84 \\
\cline { 2 - 3 } & Deviation & 0.89 \\
\cline { 2 - 3 } & & \\
\cline { 2 - 3 }
\end{tabular}

Empirical data were processed using the program STATISTICA 10 by applying the methods of descriptive statistics, reliability tests, analysis of variance - ONEWAY and multidimensional analysis of variance - MANOVA (repeated measure: intersubject factor - EFFECT, variants: 1. successful, 2. unsuccessful), factor analysis, method of principal components - VARIMAX rotation.

According to the reliability test results, the values of Cronbach alpha (Table 1) for the sets of items at individual levels range from 0.80 to 0.89 .

The research sample comprised of 743 respondents in total. Half of them were the private sector employees and the other half were the public sector employees. The research was conducted in the region of Košice, in September 2017. There were $41.67 \%$ of men and $58.33 \%$ of women in the sample.

The research sample was primarily comprised of respondents aged 26-30 (28.33\%). Age groups over 31 years are represented relatively evenly $-17.50 \%$ in the age group of $41-50$ years, $19.17 \%$ of respondents aged from 51 to 60 , and $20.83 \%$ in the age group of 31-40). In the age groups under 40 years, the number of men was higher (the majority in the age group of 16-30 years - 38\%), while in the age groups over 40 the number of women was higher than the number of men (the highest rate of $25.71 \%$ in the age group of $51-60$ years).

In terms of education, the majority of respondents reported having a university education (74.17\%). The ratio of men (80\%) and women (70\%) in this educational level is balanced.

Having in mind the intention to study inter-sectorial differences, the research sample was divided into two parallel groups - the private and the public sector, where the number of respondents was determined in the balanced ratio of private $(50 \%)$ and public (50\%) sector. The number of men in the research sample was higher in the private sector (80\%), and the number of women was higher in the public sector (71.43\%). 


\section{Results of analysis}

The studying of the character of decision-making among the public and the private sector employees revealed the tendencies in decision-making processes when solving random problems. Based on the comparison of the decision-making attributes in the instances of problem solving with successful and unsuccessful results, we can state that the decision-making methods used in both situations differ.

The data provided in Table 2 show that the differences in completed problem solving tasks are rather significant $(\mathrm{F}=3.54$ and $\mathrm{p}=0.05)$. The mean score, achieved by the overall measurements for all the attributes of particular indicators (items) in successful and unsuccessful problem solving, enables us to state that the workers incline more towards the bureaucratic rules and processes.

These are strongly oriented towards maintaining the unchanging (wrongly understood as stable) environment, preservation of an inadequately adaptable system which creates an illusion of "safety" and towards the affirmation of (uncertain) effectiveness of the processes that are built on the instability of tradition. This tendency is stronger in an instance of unsuccessfully solved problems $(M=3.12)$ than in an instance of successful solutions $(M=3.45)$. The total mean score points to the fact that the inclination towards the bureaucratic processes and ideas is not that strong; these values rather indicate a "better mean" for bureaucracy. With that said, we cannot think about the inclination towards the processes that respect the complexity of the problem being solved and the decision-making itself. Based on the results of the inter-sector differences testing, this tendency is stronger in public sector organizations, which only confirms a low adaptability rate and a high rate of typically bureaucratic algorithms in decision-making.

Table 2

Inter-situational differences in the level of inclination towards creative complexity with regard to successful/unsuccessful problem solving - total (MANOVA - intra-subject factor EFFECT)

\begin{tabular}{|c|c|c|c|c|}
\hline & \multirow{2}{*}{ F } & \multirow{2}{*}{ P } & \multicolumn{2}{|c|}{ MEAN } \\
\cline { 4 - 5 } & & & successfully & unsuccessfully \\
\hline DECISION-MAKING CHARACTER & 3.54 & $0.05^{*}$ & 3.45 & 3.12 \\
\hline
\end{tabular}

*Sign: $\mathrm{p} \leq 0.05$

Table 3 shows that inter-situational differences are only very minor, not statistically significant $(\mathrm{F}=2.06$ and $\mathrm{p}=0.15)$ in the dimension determined by the "DISINTEGRATION" indicator. The overall mean score oscillates in the middle spectrum of a 7-point scale, when slightly higher score $(M=4.46)$ and an indication of a more intensive effort to avoid the bureaucratic rules is seen in the case of successfully solved problems. This tendency is much stronger in the items with significant intersituational differences. It predominantly concerns the attitude towards traditional solutions $(\mathrm{F}=5.73$ and $\mathrm{p}=0.02)$, which is clearly freer in the cases of the decisionmaking that led to a successful solution, $(\mathrm{M}=4.46)$ in comparison to unsuccessful solutions $(M=4.11)$. The attitude towards originally set objectives is also significantly differentiated $(\mathrm{F}=3.53$ and $\mathrm{p}=0.05)$. Understanding the objectives as crucial, 
but at the same time dynamic determinants of all activities within the organization in terms of the nature of self-determining systems is, according to the measured mean values, more effective for the successful problem solving $(M=4.21)$ than in the decision-making resulting in an unsuccessful problem solution $(\mathrm{M}=3.95)$.

Other items of the "DISINTEGRATION" indicator do not show significant differences, but the mean score points to the fact that the indicated tendencies are generally relevant also in this dimension.

Table 3

Inter-situational differences in the level of inclination towards creative complexity with regard to successful/unsuccessful problem solving in the DISINTEGRATION dimension (MANOVA - intra-subject factor EFFECT)

\begin{tabular}{|c|c|c|c|c|c|}
\hline \multicolumn{2}{|c|}{ DECISION-MAKING CHARACTER } & \multirow{2}{*}{$\mathbf{F}$} & \multirow{2}{*}{$\mathrm{p}$} & \multicolumn{2}{|c|}{ EFFECTMEAN } \\
\hline \begin{tabular}{l|l} 
BUREAUCRATIC & \\
\end{tabular} & COMPLEX & & & Suc. & Unsuc. \\
\hline $\begin{array}{l}\text { It is wrong if reached } \\
\text { solutions mean deviation } \\
\text { from traditions in an } \\
\text { organization }\end{array}$ & $\begin{array}{l}\text { Creation of deviations } \\
\text { from traditions is a } \\
\text { great opportunity for an } \\
\text { organization in task solving }\end{array}$ & 5.73 & $0.02 *$ & 4.46 & 4.11 \\
\hline $\begin{array}{l}\text { It is not allowed to lead } \\
\text { the problem solutions } \\
\text { to other results than we } \\
\text { expected }\end{array}$ & $\begin{array}{l}\text { If the decision-making } \\
\text { results are different than } \\
\text { we expected, it is only } \\
\text { natural }\end{array}$ & 0.17 & 0.68 & 4.01 & 4.06 \\
\hline $\begin{array}{l}\text { Any solution must } \\
\text { definitely prevent us from } \\
\text { changing our original } \\
\text { objectives }\end{array}$ & $\begin{array}{l}\text { Changing the original } \\
\text { objectives in an } \\
\text { organization can be one } \\
\text { of very flexible problem } \\
\text { solutions }\end{array}$ & 3.53 & $0.05^{*}$ & 4.21 & 3.95 \\
\hline $\begin{array}{l}\text { It is not possible to } \\
\text { accept the solution that } \\
\text { would mean the violation } \\
\text { of the existing rules and } \\
\text { standards in no case }\end{array}$ & $\begin{array}{l}\text { Waiving the original } \\
\text { rules and standards is a } \\
\text { demonstration of a very } \\
\text { flexible and creative task } \\
\text { and problem solution }\end{array}$ & 0.53 & 0.46 & 4.33 & 4.22 \\
\hline $\begin{array}{l}\text { Accepted solution must not } \\
\text { introduce changes to the } \\
\text { existing state of things }\end{array}$ & $\begin{array}{l}\text { It is necessary to change } \\
\text { the existing state of things } \\
\text { during the problem solving } \\
\text { process }\end{array}$ & 0.68 & 0.41 & 4.04 & 3.90 \\
\hline $\begin{array}{l}\text { Solutions that would imply } \\
\text { full or partial elimination } \\
\text { of well-known work } \\
\text { methods are absolutely } \\
\text { unacceptable }\end{array}$ & $\begin{array}{l}\text { Partial or full elimination } \\
\text { of well-known work } \\
\text { methods is a necessary part } \\
\text { of creative problem solving }\end{array}$ & 0.08 & 0.77 & 4.00 & 3.95 \\
\hline \multicolumn{2}{|l|}{ Total mean } & 2.06 & 0.15 & 4.17 & 4.03 \\
\hline
\end{tabular}

*Sign: $\mathrm{p} \leq 0.05$

The differences between the problems solved with various success rates are significant $(\mathrm{F}=3.33$ and $\mathrm{p}=0.05)$ in a dimension defined by the "IRREGULARITY" indicator. The overall mean scores for decision-making attributes are generally lower in this dimension in comparison to the attributes defined by the "DISINTEGRATION" indicator. This suggests that the degree of considering the complexity of the problem and the space where the decisions are made is slightly lower. This tendency is more visible in successfully solved problems $(M=3.63)$ than in unsuccessfully solved problems $(M=3.98)$. This indicates that the irregularity rate is the character- 
istic of decision-making in a complex adaptive system that has a slightly less favourable effect on problem solving in comparison to the disintegration effects utilization. This claim is supported by the fact that even the character of differences determined by the measured mean score is not clear for individual items.

Inter-situational differences are significant in three out of six items. The difference rate is approximately the same, although the measured score varies significantly. The item measuring the interviewees' attitude towards the first ideas people involved in problem solving have indicate that this is the decision-making attribute leading the subjects to a more evident deviation from bureaucratic algorithms $(\mathrm{F}=$ 3.47 and $\mathrm{p}=0.05)$. This tendency is greater in problems solved successfully $(\mathrm{M}=$ 4.46) in comparison to unsuccessful problem solving $(M=4.26)$. If the processes employed on a regular basis are perceived as "less binding", the probability of effective problem solving is higher. It can be said that this attribute is the most significant "representative" of the given indicator. The opposite tendency was observed in the "IRREGULARITY" attribute indicating the attitude towards the possibilities of interruption of an organization's operation so that the problem solution is guaranteed. Here, the respondents' attitude is more rigid - the strongest among all of the operationalized attributes $(\mathrm{F}=3.72$ and $\mathrm{p}=0.05)$ - stronger in successful problem solving $(\mathrm{M}=2.70)$, than in unsuccessful problem solving processes $(\mathrm{M}=2.97)$.

Table 4

Inter-situational differences in the level of inclination towards creative complexity with regard to successful/unsuccessful problem solving in the IRREGULARITY dimension (MANOVA - intra-subject factor EFFECT)

\begin{tabular}{|c|c|c|c|c|c|}
\hline \multicolumn{2}{|c|}{ DECISION-MAKING CHARACTER } & \multirow{2}{*}{$\mathbf{F}$} & \multirow{2}{*}{$\mathrm{p}$} & \multicolumn{2}{|c|}{ EFFECTMEAN } \\
\hline BUREAUCRATIC & COMPLEX & & & Suc. & Unsuc. \\
\hline $\begin{array}{l}\text { The solution of the problem } \\
\text { must not challenge what has } \\
\text { been learnt so far }\end{array}$ & $\begin{array}{l}\text { To disrupt the existing learnt } \\
\text { processes is an excellent way of } \\
\text { searching the solutions }\end{array}$ & 0.60 & 0.44 & 3.95 & 3.83 \\
\hline $\begin{array}{l}\text { The problem solution must } \\
\text { maintain well-managed } \\
\text { activities }\end{array}$ & $\begin{array}{l}\text { Well-managed activities can } \\
\text { often be a hindrance in the } \\
\text { search of new solutions }\end{array}$ & 3.91 & 0.04 & 3.35 & 3.71 \\
\hline $\begin{array}{l}\text { It is necessary to find the } \\
\text { problem solution that stabilizes } \\
\text { the known ways of behaviour } \\
\text { and action }\end{array}$ & $\begin{array}{l}\text { It is necessary to search for } \\
\text { the solutions that will bring a } \\
\text { change of the established ways } \\
\text { of action }\end{array}$ & 1.87 & 0.17 & 3.46 & 3.65 \\
\hline $\begin{array}{l}\text { The best problem solution is the } \\
\text { one that is the most consistent } \\
\text { with the original ideas that } \\
\text { people had about the solution }\end{array}$ & $\begin{array}{l}\text { Original people's ideas about the } \\
\text { solution should never be binding }\end{array}$ & 3.47 & $0.05^{*}$ & 4.46 & 4.26 \\
\hline $\begin{array}{l}\text { No solution must disrupt the } \\
\text { continuity of the service in an } \\
\text { organization }\end{array}$ & $\begin{array}{l}\text { Organization operation can be } \\
\text { easily interrupted if the problem } \\
\text { solution requires it }\end{array}$ & 3.72 & $0.05^{*}$ & 2.70 & 2.97 \\
\hline $\begin{array}{l}\text { It is necessary to search for the } \\
\text { solution that will not disturb } \\
\text { anyone's work comfort }\end{array}$ & $\begin{array}{l}\text { Creative problems solutions can } \\
\text { easily disturb people in their } \\
\text { work comfort }\end{array}$ & 0.26 & 0.61 & 3.86 & 3.79 \\
\hline \multicolumn{2}{|l|}{ Total mean } & 3.53 & $0.05^{*}$ & 3.63 & 3.98 \\
\hline
\end{tabular}

*Sign: $\mathrm{p} \leq 0.05$ 
The dimension determined by the "INSTABILITY" indicator is characterized by significant differences in the types of decision-making that have led to the solution result - successful/unsuccessful $(F=4.34$ and $p=0.03)$. The total mean score for this dimension as a whole indicates a similar situation to the one presented in relation to the findings in the "IRREGULARITY" dimension. Here, the inclination towards tradition $(M=3.24)$ seems more significant for effective problem solving than considering the complexity $(\mathrm{M}=3.60)$.

\section{Table 5}

Inter-situational differences in the level of inclination towards creative complexity with regard to successful/unsuccessful problem solving in the INSTABILITY dimension (MANOVA - intra-subject factor EFFECT)

\begin{tabular}{|l|l|l|l|l|l|}
\hline \multicolumn{1}{|c|}{ DECISION-MAKING CHARACTER } & \multirow{2}{|c|}{ COMPLEX } & \multirow{2}{|c|}{$\mathbf{p}$} & \multicolumn{2}{c|}{ EFFECTMEAN } \\
\cline { 5 - 6 } & BUREAUCRATIC & Suc. & Unsuc. \\
\hline $\begin{array}{l}\text { Problem solution must be } \\
\text { completely trustful }\end{array}$ & $\begin{array}{l}\text { No solution can be completely } \\
\text { trustful }\end{array}$ & 0.49 & 0.48 & 3.31 & 3.22 \\
\hline $\begin{array}{l}\text { To find the problem solutions } \\
\text { always means to reinforce the } \\
\text { certainties in the functioning of } \\
\text { an organization }\end{array}$ & $\begin{array}{l}\text { Effective solutions can question } \\
\text { the certainties within an } \\
\text { organization operation }\end{array}$ & 13.61 & $0.00^{*}$ & 2.58 & 3.10 \\
\hline $\begin{array}{l}\text { Only the solution that has a } \\
\text { broad support in an organization } \\
\text { is effective }\end{array}$ & $\begin{array}{l}\text { Solution effectiveness does not } \\
\text { depend on a broad support in an } \\
\text { organization at all }\end{array}$ & 0.08 & 0.78 & 3.59 & 3.55 \\
\hline $\begin{array}{l}\text { The right solution must enable } \\
\text { the future development of an } \\
\text { organization to be under control }\end{array}$ & $\begin{array}{l}\text { No new solution means that } \\
\text { the future development of an } \\
\text { organization is under control }\end{array}$ & 3.31 & $0.05 *$ & 3.28 & 3.52 \\
\hline $\begin{array}{l}\text { The right solution must } \\
\text { not concern the previous } \\
\text { relationships in an organization }\end{array}$ & $\begin{array}{l}\text { The right solution must } \\
\text { definitely concern the changes in } \\
\text { the existing relationships in an } \\
\text { organization }\end{array}$ & 0.19 & 0.66 & 3.61 & 3.66 \\
\hline $\begin{array}{l}\text { It is unacceptable if problem } \\
\text { solutions bring major changes } \\
\text { into the existing organization } \\
\text { operation }\end{array}$ & $\begin{array}{l}\text { Truly effective solutions must } \\
\text { always bring the major changes } \\
\text { into the existing organization } \\
\text { operation }\end{array}$ & 4.17 & $0.04^{*}$ & 4.30 & 3.95 \\
\hline Total mean & & 3.34 & $0.03^{*}$ & 3.24 & 3.60 \\
\hline
\end{tabular}

*Sign: $\mathrm{p} \leq 0.05$

Looking at the individual attributes of this indicator, we can state that each of the operationalized attributes "lives its own life". Therefore, it is impossible to determine a clear inclination. The rate and character of the differences are very specific here. The differences in the attitude towards the reinforcement/questioning of the certainties in the functioning of an organization $(F=13.61$ and $p=0.00)$. The mean score clearly indicates that questioning certainties is not in the worker's "repertoire" - the mean score is the lowest in comparison to other attributes (for both successful and unsuccessful problem solving). It also implies that the possible "relaxation" in this context leads to less successful solutions $(M=3.10)$ in comparison to the adherence to traditions $(\mathrm{M}=2.58)$. 
Other significant differences $(\mathrm{F}=4.17$ and $\mathrm{p}=0.04)$ suggest, however, an opposite tendency in the same dimension. What we have in mind is the attribute that addresses the attitude towards the significant changes in the existing operation of an organization. It is here that the highest score in the "INSTABILITY" dimension was measured in successful problem solving $(M=4.30)$. The mean score in unsuccessful problem solving was $\mathrm{M}=3.95$. With this in mind, we can formulate an assumption that will enable us to follow the key tendencies in decision-making in the process of problem solving within organizations. The employees do not reject the changes of the existing algorithms, as long as the "stabilizing" certainties in an organization are not disturbed (or what the employees themselves regard as the certainties - which is often illusory). All measured values, except for the abovementioned highest score, in the "INSTABILITY" dimension are below 4. The overall rate of consideration of the traditional processes is evident here; although it does not mean that the subordination is entirely "blind" (except for the attitude towards the certainties within an organization).

Table 6

Inter-situational differences in the level of inclination towards creative complexity with regard to successful/unsuccessful problem solving in the DISRUPTION dimension (MANOVA - intra-subject factor EFFECT)

\begin{tabular}{|c|c|c|c|c|c|}
\hline \multicolumn{2}{|c|}{ DECISION-MAKING CHARACTER } & \multirow{2}{*}{$\mathbf{F}$} & \multirow{2}{*}{$\mathbf{p}$} & \multicolumn{2}{|c|}{ EFFECTMEAN } \\
\hline BUREAUCRATIC & COMPLEX & & & Suc. & Unsuc. \\
\hline $\begin{array}{l}\text { In problem solving it is } \\
\text { necessary to realise that most } \\
\text { of the problems respond to the } \\
\text { similar solution type }\end{array}$ & $\begin{array}{l}\text { We never start from previous } \\
\text { solutions when looking at } \\
\text { similar problems }\end{array}$ & 0.07 & 0.78 & 3.36 & 3.40 \\
\hline $\begin{array}{l}\text { The best problem solutions are } \\
\text { those that make full use of the } \\
\text { existing work processes }\end{array}$ & $\begin{array}{l}\text { The most effective solutions } \\
\text { never rely on the use of the } \\
\text { existing work processes }\end{array}$ & 1.36 & 0.24 & 3.31 & 3.46 \\
\hline $\begin{array}{l}\text { The best problem solution does } \\
\text { not necessarily demand the } \\
\text { change of the existing way of } \\
\text { thinking }\end{array}$ & $\begin{array}{l}\text { The best solutions demand the } \\
\text { change of the existing way of } \\
\text { thinking }\end{array}$ & 0.16 & 0.69 & 4.17 & 4.1 \\
\hline $\begin{array}{l}\text { The most effective problem } \\
\text { solutions do not require to pay } \\
\text { attention to different topics as } \\
\text { we did in the past }\end{array}$ & $\begin{array}{l}\text { The most effective solutions } \\
\text { demand opening new topics } \\
\text { that had not been addressed yet }\end{array}$ & 2.07 & 0.15 & 4.39 & 4.19 \\
\hline $\begin{array}{l}\text { The problem solution must not } \\
\text { disturb the present relations } \\
\text { with the external environment } \\
\text { of an organization }\end{array}$ & $\begin{array}{l}\text { The problem solution must } \\
\text { impact the relations with the } \\
\text { external environment of an } \\
\text { organization }\end{array}$ & 0.05 & 0.82 & 3.34 & 3.31 \\
\hline $\begin{array}{l}\text { The most beneficial solution } \\
\text { does not demand a radical } \\
\text { change in the management and } \\
\text { decision-making style }\end{array}$ & $\begin{array}{l}\text { Radical changes in the } \\
\text { management style are a } \\
\text { requirement for the effective } \\
\text { application of solutions }\end{array}$ & 5.02 & $0.02 *$ & 3.82 & 3.54 \\
\hline \multicolumn{2}{|l|}{ Total mean } & 1.96 & 0.12 & 3.73 & 3.67 \\
\hline
\end{tabular}

*Sign: $\mathrm{p} \leq 0.05$

In the dimension of "DISRUPTION", the differences in the level of inclination towards the bureaucracy/complexity that determine the successfulness of problem solving are not statistically significant $(\mathrm{F}=1.96$ and $\mathrm{p}=0.12)$. The total mean score 
for this dimension as a whole indicates almost indecisive attitudes, with a higher score $(\mathrm{M}=3.73)$ for successful problem solving, and a lower inclination towards bureaucracy for unsuccessful problem solving $(M=3.67)$. The tendency, however, cannot be determined since the differences are minimal.

Typical of the whole "DISRUPTION" dimension are the small inter-situational differences. They are significant only in the attitude towards the radical change in the management style $(F=5.02$ and $p=0.02)$. The mean scores indicate that the greater deviation from the traditional schemes is more effective $(M=3.82)$ in successful problem solving, while the unsuccessful problem solving score is $\mathrm{M}=3.54$.

A significantly higher level of inclination towards complex processes was determined in the attitude towards the key topics when the inclination towards the opening of new topics is more effective $(M=4.39)$. Since this is also the highest mean score in this dimension, we can state that creativity and variability in the thematisation of organizational mechanisms seems to be relevant for the effectiveness of problems solving. The attitude towards the change of the existing way of thinking proves to be similar, even though less intense. On the other hand, the most rigid are the attitudes towards the maintenance/disruption of the existing relations with the external environment. We can assume that the respondents saw this disruption as a negative phenomenon with no developmental potential.

\section{Table 7}

Inter-situational differences in the level of inclination towards creative complexity with regard to successful/unsuccessful problem solving in the DEVIATION dimension (MANOVA - intra-subject factor EFFECT)

\begin{tabular}{|c|c|c|c|c|c|}
\hline \multicolumn{2}{|c|}{ DECISION-MAKING CHARACTER } & \multirow{2}{*}{$\mathbf{F}$} & \multirow{2}{*}{$\mathbf{P}$} & \multicolumn{2}{|c|}{ EFFECTMEAN } \\
\hline BUREAUCRATIC & $\begin{array}{r}\text { COMPLEX } \\
\end{array}$ & & & Suc. & Unsuc. \\
\hline $\begin{array}{l}\text { For every problem, it is necessary } \\
\text { to find the solution that will not } \\
\text { "upset" the established system }\end{array}$ & $\begin{array}{l}\text { Effective solutions will } \\
\text { necessarily cause "the upset" of } \\
\text { the established system }\end{array}$ & 0.80 & 0.37 & 3.67 & 3.56 \\
\hline $\begin{array}{l}\text { Problem solution must not } \\
\text { challenge the existing working } \\
\text { processes }\end{array}$ & $\begin{array}{l}\text { Problem solution must } \\
\text { immediately challenge the } \\
\text { existing working processes }\end{array}$ & 4.65 & $0.03^{*}$ & 3.19 & 3.45 \\
\hline $\begin{array}{l}\text { It is necessary to find the } \\
\text { problem solution that will not } \\
\text { impact the present organizational } \\
\text { structures }\end{array}$ & $\begin{array}{l}\text { Every effective solution will } \\
\text { impact the present organizational } \\
\text { structures }\end{array}$ & $3, .3$ & $0.05^{*}$ & 3.74 & 3.61 \\
\hline $\begin{array}{l}\text { The solution that "protects the } \\
\text { existing working methods" is } \\
\text { always right }\end{array}$ & $\begin{array}{l}\text { No effective problem solution } \\
\text { will "protect" the existing } \\
\text { working methods }\end{array}$ & 3.43 & $0.05^{*}$ & 4.06 & 3.84 \\
\hline $\begin{array}{l}\text { The best solutions are those that } \\
\text { everybody agrees with }\end{array}$ & $\begin{array}{l}\text { It is not possible, or necessary } \\
\text { for everybody to agree with the } \\
\text { problem solution }\end{array}$ & 4.38 & $0.03^{*}$ & 4.68 & 4.50 \\
\hline $\begin{array}{l}\text { The problem solution must also } \\
\text { confirm the validity of standard } \\
\text { processes }\end{array}$ & $\begin{array}{l}\text { It is impossible to confirm the } \\
\text { validity of standard processes by } \\
\text { an effective problem solution }\end{array}$ & 0.48 & 0.49 & 3.82 & 3.74 \\
\hline Total mean & & 3.1 & $0.05^{*}$ & 3.87 & 3.58 \\
\hline
\end{tabular}

*Sign: $\mathrm{p} \leq 0.05$ 
The dimension determined by the "DEVIATION" indicator is characterized by significant differences between the decision-making processes in successful/unsuccessful problem solving $(\mathrm{F}=3.31)$. The total mean score of the dimension as a whole (Table 7) indicates that the "relaxing" of traditional algorithms leads to successful problem solving within an organization. However, the score that is higher in successful problem solving $(M=3.87)$, in comparison to unsuccessful problem solving $(M=$ 3.58), remains in the slightly bureaucratic or indecisive spectrum. Therefore, we cannot talk about the significant inclination towards the complex decision-making processes for this indicator.

Individual attributes also showed inclinations that are more significant. Inter-situational differences are significant for four out of six attributes. The rate of differences is very similar, whereas the characters of differences are dissimilar. The tendencies in the attitude towards the individual attributes are evident regardless of their link to successfulness/unsuccessfulness of problem solving. The attitude towards the employees' agreement/disagreement with the adopted solutions represents the greatest deviation from the bureaucratic algorithms. Given the mean score, we can state that a greater deviation from bureaucracy $(\mathrm{M}=4.68)$ leads to more effective results of the problem solving process.

On the other hand, the preservation of traditional patterns is most evident in the attitude towards questioning of the existing processes $(F=4.65$ and $p=0.03)$. The mean scores reveal that the questioning of the existing functional processes leads to unsuccessful problem solving $(\mathrm{M}=3.45)$; the mean score for successful problem solving is $\mathrm{M}=3.19$.

The results of the analysis show that the indicator "DEVIATION" from traditions, expectations, goals and standards, as well as the known and the predictable, is also characterized by certain specifics linked to the uniqueness of individual decisionmaking attributes.

\section{Discussion}

The research into the differences in the methods and decision-making processes in terms of determining which of them is more effective in solving problem situations in various organizations indicates that employees incline more towards the bureaucratic attributes than the complex ones; and that is regardless of the nature of the organization. Several factors are at play here - either individually or in coaction, which can often magnify their effects.

Firstly, the way that the majority perceives, understands, explains and further creates a specifically human environment (including the organizational environment) is associated with the straightforward linear thinking in terms of moving from "point A to point B", in line with the previously known, taught, planned, controlled or externally defined processes, while excluding any "undesirable" surprises or unexpected events. 
The concept of surprise is the key phenomenon in the behaviour of complex adaptive systems. It is usually defined by unexpected events at any time, expressed in a variety of ways. It shows the movement beyond the planned control and involves the unexpected changes or results. "For many people who manage or direct the actions of others in an organization, surprises are seen to be unwelcome moments that sometimes evoke a feeling of discomfort, prompting the need to know more, plan better, or design better systems to avoid the possibility of any unexpected surprises" (Stanley, 2009:46; McDaniel at al., 2003; Weick and Sutcliffe, 2001). Stanley defines surprise as a phenomenon based on the illusion of stability and expectation. The starting point for such perception is whether one is capable of seeing the external reality in all aspects as true and optimal. With that said, even the starting position of a subject who creates strategies, rules, and algorithms of behaviour within an organization is not fully consistent with the character of all attributes of input conditions. Therefore, the linearly structured organizational systems are constantly confronted with surprises that significantly disturb the stability of the system, and produce deviations in the system behaviour and its consequences. Surprises are associated with uncertainty and, in some cases, arising from some discrepancy between the behaviour of a certain open system through its interactions within the larger context of that system (the "outside") and the behaviour of a closed system to those same interactions (Casti, 1992).

Secondly, both internal and external environments of an organization, especially its control mechanisms, presuppose or require this linear model of decision-making, all in an effort to reduce uncertainties.

Uncertainty is the main issue resulting from complexity (Rzevski, 2011). The effort of bureaucracy to regulate and control the environment of emergent phenomena of an organization as a complex adaptive system has to do with the reduction of uncertainty (uncertainty zones - Crozier, 1964) to a minimum. As Simon (1999) explains in his theory of bounded rationality, this happens as the so-called reduction of the decision-making burden (in order to avoid chaos caused by creating alternatives), through defined and "control-guarded" algorithms designed to block the production of additional options. The result is, among other things, the change of objectives (Merton, 1957), where the goal is not to use the effective means, but to comply with the rule. This is how the instruments of bureaucracy are utilized to displace the complex nature of the system and, on the outside, present it as a simple linear model. Any existing efforts of bureaucracy to ensure a certain degree of harmonization in this respect are only partial solutions and these do not take into account the nature of the system (bureaucracy as power arrangement). The emergent phenomena in such a system cannot be regulated or controlled (if so, only to a certain extent), and thus the "certainties of bureaucracy" (the effectiveness of its instruments) become a delusion, and the predetermined parameters of the system behaviour transform into surprises produced by uncertainty (Nebeker, 1975).

Thirdly, although an organizational environment is of a complex nature, the rules and procedures are structured to create an illusion that it is necessary to minimize uncertainties as something undesirable and that adhering to a certain procedure 
guarantees undisputedly successful solutions. Thus, the favourable conditions in which the attributes of creative complexity can be actualised (uncertainty) are lost.

All "manifestations" of creativity (Rouse, 1999) can be seen as highly destructive in relation to a classical concept of system stability, or are understood as the naturally evolving areas for creating new behavioural patterns with respect to the current configuration of events. Stacey (1996) discusses the creative destruction which, at the agent level in a self-organization, requires the spontaneous production of emergent strategies. The resulting reaction to stimuli is always a combination of several available options, or rather input information, and the so-called mental models as cognitive maps (Kuhn, 1970) in an individual design. Individual schemes are subsequently shared by agents and lead to action, that is, the strategies that the agent accepted as beneficially possible and effective. Communication is characterized by its multidimensionality.

Although the results of empirical analysis show a greater inclination towards bureaucratic attributes, this is not self-evident. The majority of the mean scores are in the middle spectrum of the seven-point scale. There were no extreme values recorded. On one hand, this can mean "indecisiveness" in the inclination. On the other hand, however, this result can be a validation of the complexity and variability of the produced situations and patterns of the decision-making process, which can be explained as the fact that the complexity of an organizational environment requires flexibility even in an inclination towards certain decision-making models. The results of the analysis indicate that some problems can be successfully solved using bureaucratic procedures, while a solution of other problems requires more complex decision-making. Stacey (1996) refers to such a situation as the "state of paradox". This tendency is particularly evident in the "IRREGULARITY" and "INSTABILITY" dimensions.

\section{Conclusion}

Based on the results obtained from the analysis of problem solving and decisionmaking within organizations in terms of the nature of bureaucratic/complex (creative) schemes in five different dimensions, defined by complexity indicators, we can conclude that the assumption formulated in the hypothesis was confirmed for three indicators: 1. Irregularity, 2. Instability and 3. Deviation.

The obtained data revealed that there are some indications of the employees' inclination towards complex decision-making. Being mostly within the spectrum, which does not necessarily mean a considerable support for bureaucracy, they oscillate in the interspace between bureaucracy and complexity.

Especially the dimension of "IRREGULARITY" shows that complex adaptive systems are indeed the systems defined in complexity paradoxes, as discussed in the theoretical part (Stacey, 1996). Complexity cannot be approached within a structure of the algorithm that would confirm the notion that complex equals successful. The 
uniqueness of every situation calls for sensitive, flexible, and creative decisionmaking. It might suggest the necessity to create situations in which the use of traditional processes seems to be the most effective. The mean score suggests that the inclination towards the employment of traditional processes, such as maintaining well-managed activities, providing consolidation of the known processes of behaviour, not disrupting the continuity of the service - proved to be more successful in three attributes of the indicator.

Similarly, the findings concerning the dimension of "INSTABILITY" show that we cannot state with great certainty that the rate and the character of the observed differences follow some pattern. We need to emphasize the distinctive variability of patterns and specifics with regard to the operationalized attributes of decisionmaking. The mean scores indicate that trust ( $M$ for successful/unsuccessful solution is identical $=3.31$ ) is one of the attributes that requires consideration of a traditional view. As the saying goes, we can only trust in what we know. The degree of unpredictability in complexity does not provide a sufficient basis for trust (since we do not know what to trust). Complexity management, however, provides alternatives of the process creation for such cases, too.

The results of the empirical data analysis in the "DISINTEGRATION" dimension support a greater degree of successful problem solving in the inclination towards the attributes of creative complexity. Disintegration, as one of the important features of complex adaptive systems, is not a mechanism that influences the organizational processes negatively, as claimed by supporters of traditional approaches. Just the contrary. It carries the potential of system development and the possibility to create new, previously unintended alternatives of the solutions. Subsequently, the disintegration of traditional processes, structures, methods, consensus, and standards can lead to desirable effects in organizations in terms of their development.

The rate and character of the inter-situational differences point to the typical features of complex adaptive systems, defined in complexity paradoxes and constituting a key support scheme for the theoretical-conceptual framework of the analysis. It means that there is no clear tendency that would create a single pattern implying that the higher level of inclination towards complexity means more successful problem solving. The situations in which traditional algorithms ensure successful solutions are also relevant. 


\section{References}

1. Allen, P. (2001). „What Is Complexity Science? Knowledge of the Limits of Knowledge.". Emergence, 3 (1): 24-42.

2. Argyris, C. D. and Schön, D. (1978). Organizational Learning: A Theory of Action Perspective. Reading, MA: Addison-Wesley.

3. Ashby, W. R. (1947). Principles of Self-organizing System. Journal of General Psychology, 37: 125-128.

4. Axelrod, N. N. and Cohen, M. D. (2000). Harnessing Complexity: Organizational Implications of a Scientific Frontier. New York: Basic Books.

5. Baoquan, L. and Guishi, D. (2002). Multidimensional Dynamic Systems Analysis Theory. An Introduction. Emergence, 4(3): 36-53doi: 10.1207/S15327000EM0403-04

6. Barnard, Ch. I. (1938). The Functions of the Executive. Cambridge, Mass: Harvard University Press.

7. Blauner, R. (1964). Alienation and Freedom. Chicago: University of Chicago Press.

8. Boken, R. M. (2000). An Alternative Sports Metaphor for Understanding Teamwork as Complex: Soccer. Emergence: Complexity \& Organization, 11 (2): 79-86.

9. Boschetti, F. (2011). Rationality, Complexity and Self-Organization. Emergence: Complexity \& Organizations, 13 (1-2): 133-145.

10. Boschetti, F.; Hardy, P. Z.; Grigg, N.; Horowitz, P. (2001). Can We Learn How Complex Systems Work? Emergence: Complexity \& Organization, 13 (4): 47-62.

11. Carlisle, Y. and Mc Millan, E. (2006). Innovation in Organizations from a Complex Adaptive Systems Perspective. Emergence: Complexity \& Organizations, 8 (1): 2-9.

12. Casti, J. L. (1992). Reality Rules: Picturing the World in Mathematics - The Fundamentals. Wiley, New York.

13. Casti, J. (1997). Would Be Worlds. New York: John Wiley.

14. Cilliers, P. (1998). Complexity and Postmodernism. Understanding Complex Systems. New York: Routledge.

15. Clapham, M. M. (1997). Ideational Skills Training: A Key Element in Creativity Training Programs. Creativity Research Journal, 10 (1): 33-44.

16. Crozier, M. (1964). Le phénomene bureaucratique. Paris, Seuil.

17. Crozier, M. (1970). La société bloquée. Paris, Seuil.

18. Daneke, G. A. (2005). The Reluctant Resurrection: New Complexity Methods and Old Systems Theories. Journal of Public Administration, 28: 89-106.

19. Desai, D. A. (2010). Co- creating Learning: Insights from Complexity Theory. The Learning Organization, 17 (5): 388-403.

20. Dooley, K. J. and Letiche, H. (2009). Guest Editorial: Complexity and Environment. Emergence: Complexity \& Organization, 11 (3): vi-viii.

21. Crawford, K.; Hasan, H.; Warne, L.; Linger, H. (2009). From Traditional Knowledge Management in Hierarchical Organizations to a Network Centric Paradigm for a Changing World. Emergence: Complexity \& Organizations, 11 (1): 1-18.

22. Eide, T. (2009). Understood Complexity: Ibsen's 'An Enemy of the People' - On Complexity, Sense-Making, Understanding, and Exit/Voice/Loyalty. Emergence: Complexity \& Organization, 11 (3): 1-15.

23. Goertzel, B. (1994). Chaotic Logic. Language, Thought, and Reality from the Perspective of Complex Systems Science. New Zealand: University of Waikato, Hamilton. 
24. Goldstein, J. A. (1994). The Unshackled Organization: Facing the Challenge of Unpredictability through Spontaneous Reorganization. Portland: Productivity Press.

25. Goldstein, J. A. (2007). A New Model for Emergence and its Leadership Implications, in: Hazy, J.; Goldstein, J. A. and Lichtenstein, B. (Eds.). Complex Systems Leadership Theory. Portland: Productivity Press, pp. 61-92.

26. Goldstein, J. A. and Hazy, J. K. (2008). Complexity and the Generation of Social Value. Emergence: Complexity \& Organization, 10 (3): vi-x.

27. Golembiewski, R. T. (1979). Approaches to Planned Change. New York: Dekker.

28. Gouldner, A. W. (1954). Patterns of Industrial Bureaucracy. Glencoe, Free Press.

29. Hazy, J. K. and Ashley, A. S. (2011). Unfolding The Future: Bifurcation In Organizing Form And Emergence In Social Systems. Emergence: Complexity E Organization, 13 (3): 57-79.

30. Heckscher, Ch. and Donnellon, A. (1994). The Post-Bureaucratic Organization. New Perspective on Organizational Change. Thousand Oaks, Sage Publications.

31. Hodgson, G. M. (2000). The Concept of Emergence in Social Science: Its History and Importance. Emergence, 2 (4): 65-77.

32. Homans, G. C. (1950). The Human Group. New York: Harcourt.

33. Chamberlin, W. (2009). Networks, Emergence, Iteration and Evolution. Emergence: Complexity \& Organization, 11 (4): 91-98.

34. Jakubik, M. (2008). Experiencing Collaborative Knowledge Creation Processes. The Learning Organization, 15 (1): 5-25.

35. Kemp, S. (2009). Unpredictability and Nonlinearity in Complexity Theory: A Critical Appraisal. Emergence: Complexity \& Organizations, 11 (1): 84-93.

36. Kuhn, T.S. (1970). The Structure of Scientific Revolution. Chicago: University of Chicago Press.

37. Lissack, M. R. and Letiche, H. (2002). Complexity, Emergence, Resilience, and Coherence: Gaining Perspective on Organizations and their Study. Emergence, 4 (3): 72-94.

38. Luhman, N. (1997). Die Gesellschaft der Gesellschaft (2 vols). Frankfurt am Main: Suhrkamp.

39. McDaniel, Jr. R. R.; Jordan, M. E. and Fleeman, B. F. (2003). Surprise, Surprise, Surprise! A Complexity Science View of the Unexpected. Health Care Management Review, 28(3): 266-268.

40. McKelvey, B. (2002). Managing Coevolutionary Dynamics. Paper presented at the 18th EGOS.

41. Merton, R. K. (1936). Unanticipated Consequences of Purposive Social Action. Administrative Science Review, 1 (6): 894-904.

42. Merton, R. K. (1957). Social Theory and Social Structure. Glencoe, Free Press.

43. Merton, R. K. (1952). Reader in Bureaucracy. Glencoe, Free Press.

44. Mintzberg, H.; Raisinghani, D. and Théorêt, A. (1976). The Structure of Unstructured Decision Processes. Administrative Science Quarterly, 21 (2): 246-275.

45. Moldoveanu, M. (2008). Organizations as Universal Computing Machines: Rule Systems, Computational Equivalence, and Organizational Complexity. Emergence: Complexity \& Organization, 10 (1): 2-22.

46. Molleman, E. (1998). Variety and the Requisite of Self-organization. International Journal of Organizational Analysis, 6 (2): 109-131.

47. Morcöl, G. (2001). What Is Complexity Science? Postmodernist or Postpositivist? Emergence, 3 (1): 104-119. 
48. Nebeker, D. M. (1975). Situational Favorability and Perceived Environmental Uncertainty: An Integrative Approach. Administrative Science Quarterly, 20: 281-294.

49. Phelan, S. E. (2001). What Is Complexity Science, really? Emergence, 3 (1): 120136.

50. Priesmeyer, H. R. (1992). Organizations and Chaos. Defining the Methods of Nonlinear management. London: Quorum Books.

51. Rouse, W. B. (1999). Connectivity, Creativity, and Chaos. Information Knowledge Systems Management, 1 (2): 117-132.

52. Rzevski, G. (2011). A Practical Methodology For Managing Complexity. Emergence: Complexity \& Organizations, 13 (1-2): 38-56.

53. Saadia, M. (2009). Framework for the Role of Self-Organizing in the Handling of Adaptive Challenges. Emergence: Complexity \& Organization, 11 (2): 1-14.

54. Schumpeter, J. A. (1934). The Theory of Economic Development. Cambridge, MA: Harvard University Press.

55. Simon, H. A. (1999). Bounded Rationality and Organizational Learning. Reflections, 1 (2): 17-28.

56. Smith, G. F. (1996). Identifying Quality Problems: Prospects for Improvement. Total Quality management, 7 (5): 535-552.

57. Stacey, R. D. (1996). Complexity and Creativity in Organizations. San Francisco: Berrett-Koehler Publishers.

58. Stacey, R. D. (2001). Complex Responsive Processes in Organizations. Learning and Knowledge Creation. London: Routledge.

59. Stanley, D. (2009). Complexity and the Phenomenological Structure of „surprise". Emergence: Complexity \& Organization, 11 (2): 46-53.

60. Surie, G. and Hazy, J. (2006). Generative Leadership: Nurturing Innovation in Complex Systems. Emergence: Complexity E Organization, 8 (5): 13-26.

61. Tapsell, P. and Woods, C. (2008). A Spiral of Innovation Framework for Social Entrepreneurship: Social innovation at the Generational Divide in an Indigenous Context. Emergence: Complexity \& Organization, 10 (3): 25-34.

62. Taylor, F. W. (1947). Scientific Management. New York Harper and Row.

63. Thietart, R. A. and Forgues, B. (1995). Chaos theory and organization. Organizational Science, 6 (1): 19-31.

64. Varga, L.; Allen, P. M.; Strathern, M.; Rose-Andersen, Ch. (2009). Sustainable Supply Networks: A Complex Systems Perspective. Emergence: Complexity \& Organization, 11 (3): 16-36.

65. Wallis, E. S. (2009). The Complexity of Complexity Theory: An Innovative Analysis. Emergence: Complexity \& Organization, 11 (4): 26-38.

66. Weber, M. (1922). Wirtschaft und Gesellschaft. Tubingen: J.C.B. Mohr.

67. Weber, M. (1947). The Theory of Social and Economic Organization. New York: Free Press.

68. Weick, K. E. and Sutcliffe, K. M. (2001). Managing the Unexpected: Assuring High Performance in an Age of Complexity. San Francisco: Jossey-Bass.

69. White, O.F. Jr. (1969). The Dialectical Organization: An Alternative to Bureaucracy. Public Administration review, 29 (1): 32-42.

70. Winnicott, D. W. (1965). The Maturational Process and the Facilitating Environment. London: Hogarth Press. 


\author{
Eva Bolfiková* \\ e-mail:eva.bolfikova@unipo.sk \\ Ivana Pirohová* \\ e-mail: ivana.pirohova@unipo.sk \\ Martina Lenhardtová * \\ e-mail: martina.lenhardtova@unipo.sk
}

Katarína Mayer*

e-mail: katarina.mayer@unipo.sk

Marek Lukáč *

e-mail:marek.lukac@unipo.sk

Daniela Hrehová

Tehničko sveučilište, Odjel za društvene znanosti, Košice, Slovačka

e-mail: daniela.hrehova@tuke.sk

* Sveučilište u Prešovu, Fakultet humanističkih i prirodnih znanosti, Odjel za andragogiju, Slovačka

\title{
Birokracija i kreativna kompleksnost - empirijska analiza učinkovitosti rješavanja problema u organizacijama
}

\section{Sažetak}

Istraživanje predstavlja teorijsku i empirijsku analizu birokratskih i ne-birokratskih alata za rješavanje problema u organizacijama koje se smatraju kompleksnim adaptivnim sustavima. Polazeći od Stacyine teorije kreativne kompleksnosti, osmislili smo istraživački okvir sastavljen od pet indikatora (dimenzija): dezintegracija, nepravilnost, nestabilnost, disrupcija te devijacija (svaki od indikatora dalje je operacionaliziran u šest pitanja u upitniku). Imajući na umu istraživačku hipotezu, analizirali smo sklonost donošenju odluka slijeđenjem birokratske logike (linearnoga okruženja) s jedne strane, te logike kreativne kompleksnosti s druge. Razina sklonosti analizirana je u usporedbi s učinkovitošću rješavanja problema korištenjem metode ponovljene mjere MANOVA - (intersubjektivni faktor - UČINAK: 1. uspješan, 2. neuspješan). Sudionici istraživanja bila su 743 zaposlenika različitih organizacija. U istraživanju je korištena metoda upitnika K-T-1. Rezultati analize pokazali su da se stupanj uspjeha u rješavanju problema značajno razlikuje u tri dimenzije: nepravilnost, nestabilnost i devijacija. Veća sklonost kreativnoj kompleksnosti pronađena je u dvije dimenzije: devijacija i pravilnost. Veći uspjeh u rješavanju problema slijedeći birokratsku logiku pronađen je u dimenziji nestabilnost.

Ključne riječi: birokracija, kompleksni adaptivni sustav, organizacija, kreativna kompleksnost. 